\title{
PERBEDAAN PERUBAHAN FUNGSI HEMOSTASIS SAAT STABILISASI PREEKLAMSIA BERAT/EKLAMSIA 24 JAM POSTPARTUM
}

\author{
Hudila Rifa Karmia ${ }^{1}$, Yusrawati ${ }^{1}$, Hafni Bachtiar ${ }^{2}$
}

\begin{abstract}
Abstrak
Penelitian bertujuan menganalisis perbedaan perubahan temuan fungsi hemostasis saat stabilisasi antara preeklamsia berat/eklamsia yang mengalami dan yang tidak mengalami perbaikan 24 jam postpartum. Pada subyek penelitian yaitu wanita preeklamsia berat/eklamsia yang mengalami dan tidak mengalami perbaikan 24 jam postpartum dan memenuhi kriteria inklusi (16 pasien per kelompok) dilakukan pemeriksaan laboratorium fungsi hemostasis di Labor Patologi Klinik RSUP M. Djamil Padang. Perbedaan perubahan temuan fungsi hemostatik pada kedua grup dianalisa dengan menggunakan t-test. Dari penelitian didapatkan perbedaan temuan fungsi hemostasis pada saat stabilisasi antara preeklamsia berat/eklamsia yang mengalami dan yang tidak mengalami perbaikan 24 jam postpartum adalah trombosit $40.000 \pm 39.653 / \mathrm{ml}$ banding $-5.250 \pm 58.915 / \mathrm{ml}(\mathrm{p}=0,016)$, PT $-0,144 \pm 1,083$ detik banding $0,038 \pm 1,549$ detik $(p=0,074)$, APTT $-0,275 \pm 3,938$ detik banding $1,55 \pm 4,99$ detik $(p=0,260)$, dan D-dimer $0,319 \pm 1,34 \mathrm{ug} / \mathrm{L}$ banding $0,7125 \pm 2,018 \mathrm{ug} / \mathrm{L}(\mathrm{p}=0,521)$. Sehingga dapat disimpulkan bahwa terdapat peningkatan yang bermakna secara statistik kadar trombosit kelompok yang mengalami perbaikan dibandingkan kelompok yang tidak mengalami perbaikan. Tidak terdapat perbedaan bermakna kadar PT, APTT, dan D-Dimer antara kelompok yang mengalami perbaikan dan kelompok yang tidak mengalami perbaikan.
\end{abstract}

Kata Kunci: perubahan fungsi hemostasis, preeklamsia berat, eklamsia

\section{Abstract}

This study aimed to analyze the differences in hemostatic function changes during stabilization phase between severe preeclampsia/eclampsia patients with and without improvement in 24 hours postpartum. Women with severe preeclampsia/eclampsia with improvement and without improvement in 24 hours postpartum (16 patients for each group) whom meet the inclusion criteria were subjected a laboratory test of hemostatic function in laboratory of Clinical Pathology of RSUP M. Djamil Padang. The differences in hemostatic function changes between the two groups were analysed by using independent $t$-test. The result showed the differences in hemostatic function during stabilisation phase between severe preeclampsia/eclampsia with and without improvement in 24 hours postpartum. Thrombocyte was $40,000 \pm 39,653 / \mathrm{ml}$ vs $-5,250 \pm 58,915 / \mathrm{ml}(p=0.016)$, PT was $-0.144 \pm 1.083$ seconds vs $0.038 \pm 1.549$ seconds $(p=0.074), A P T T$ was $-0.275 \pm 3.938$ seconds vs $1.55 \pm 4.99$ second $(p=0.260)$, and $D$-dimer was $0.319 \pm 1.34 \mathrm{ug} / \mathrm{L}$ vs $0.7125 \pm 2.018 \mathrm{ug} / \mathrm{L}(p=0.521)$. In conclusion, there was a statistically significant increase of trombosit levels in the group with improvement than those without improvement. There were no significant differences of the levels of PT, APTT, and D-Dimer between the two groups.

Key words: hemostatic function changes, severe preeclampsia, eclampsia

Afiliasi Penulis: 1. Divisi Fetomaternal Bagian Obstetri dan Ginekologi RSUP M. Djamil Padang/Fakultas Kedokteran Universitas Andalas, 2. Bagian IImu Kesehatan Masyarakat Fakultas Kedokteran Universitas Andalas. Korespondensi: Hudila Rifa Karmia, email: hudilarifakarmia@yahoo.co.id, Telp/Hp:

+62811660916 . 


\section{PENDAHULUAN}

Hipertensi yang merupakan komplikasi kehamilan masih merupakan penyebab utama morbiditas dan mortalitas meternal dan fetus. Sebahagian besar morbiditas ini dihubungkan dengan preeklampsia, yaitu kelainan di mana tekanan darah yang tinggi merupakan satu aspek dari penyakit ini yang menimbulkan efek merusak berbagai sistem organ. ${ }^{1,2,3}$

Penyakit yang saat ini dikenal dengan preeklampsia sebenarnya telah lama dikenal. Penyakit ini mulai dikenal di Mesir, pada tahun 2200 SM, di mana pasien hamil yang mengalami kejang-kejang pada dagu dianggap disebabkan adanya rasa gatal pada uterus. Pada zaman Hippocrates telah dinyatakan bahwa kehamilan yang disertai sakit kepala berat, mengantuk dan kejang biasanya berakibat buruk/fatal. Pada abad pertama Masehi baru dikenal bahwa pada pasien hamil yang mengalami kejang ditemukan nadi yang kuat (strong) dan bengkak/edema (swollen). Proteinuria diketahui berhubungan dengan kehamilan yang disertai edema (tapi tidak dijelaskan kapan kenyataan itu ditemukan). Adanya hipertensi pada pasien hamil dengan proteinuria atau kejang baru diketahui setelah adanya penemuan sphygmomanometer tahun $1875 .^{1}$

Semenjak diketahui bahwa pada pasien hamil yang mengalami edema, proteinuria atau kejang selalu didapatkan hipertensi, maka sejak dulu sampai sekarang hipertensi dan kelainan neurologi (kejang) menjadi fokus utama dalam membicarakan penyakit ini, baik dalam hal patofisiologi, klasifikasi, diagnosis, penatalaksanaan dan prognosis. American College of Obstetrics and Gynecology, 1986, menggolongkan penyakit ini ke dalam hipertensi, yaitu hipertensi yang berkembang dalam kehamilan dan nifas. Preeklampsia didefinisikan sebagai terjadinya hipertensi dengan proteinuria, edema, atau keduanya, dan dipicu oleh kehamilan setelah 20 minggu. ${ }^{4,5}$

Dewasa ini patofisiologi preklampsia dianggap karena adanya kerusakan dan disfungsi endotel, yang memicu timbulnya maternal sindrome, dimana setiap organ dapat dikenai atau terganggu fungsinya tanpa harus terjadi gangguan vaskuler (hipertensi) dan gangguan neurologi (kejang) terlebih dahulu; artinya akan terdapat berbagai manifestasi pada penyakit ini (protean syndrome). Mekanisme patofisiologi dapat terjadi pada organ manapun (sistem kardiovaskuler, sistem hematologi, ginjal, hepar, otak dan mata). Gejala yang muncul pada masing masing individu pun berbeda beda, tergantung dari organ mana yang lebih dominan dipengaruhi dibanding organ lainnya. ${ }^{6,7,8}$

Meski diakui bahwa terapi utama preeklampsia/eklampsia adalah pengeluaran plasenta, dan preeklampsia/eklampsia merupakan protean syndrome, namun penatalaksanaan penyakit ini masih berfokus pada penurunan tekanan darah dan mencegah/mengatasi kejang. ${ }^{4}$ Di RS M. Djamil Padang dilakukan stabilisasi selama 4-6 jam (dengan pemberian antihipertensi dan anti kejang) sebelum dilakukan terminasi kehamilan. ${ }^{9,10}$ Pemberian anti kejang (magnesium sulfat) diberikan sampai 24 jam pospartum. ${ }^{2}$ Oleh sebab itu timbul pertanyaan, apakah dengan pengendalian efek pada vaskuler (pengendalian tekanan darah) dan pengendalian terhadap efek neurologis (mencegah/mengatasi kejang) efek pada organ lain, terutama sistem hemostasis (yang 
dinilai secara objektif melalui temuan laboratoris) ikut terkendali atau tetap progresif; dan apakah temuan laboratoris sistem hemostatis itu berbeda antara kasus preeklampsia/eklampsia yang mengalami perbaikan dan yang tidak mengalami perbaikan.

\section{METODE}

Penelitian ini merupakan penelitian observasional dengan membandingkan temuan laboratoris antara kasus preeklampsia berat/eklampsia yang mengalami perbaikan dan yang tidak mengalami perbaikan. Desain penelitian yang dipilih adalah cross sectional, karena data variabel bebas (perjalanan klinis pasien yang diklasifikasi menjadi 'mengalami perbaikan' dan 'tidak mengalami perbaikan') dan data variabel terikat (temuan laboratoris fungsi hemostatis) diambil dalam periode waktu yang sama, yaitu periode sejak pasien masuk rumah sakit sampai 24 jam pospartum.

Penelitian dilaksanakan di Kamar Bersalin dan HCU SMF Kebidanan dan Kandungan RS M. Djamil Padang. Pemeriksaan sampel darah dilakukan di Instalasi Patologi Klinik RS M. Djamil Padang. Sampel berjumlah masing-masing 16 orang untuk per kelompok. Kriteria Inklusi belum mendapatkan pengobatan sebelum masuk RS M. Djamil Padang, sedangkan Kriteria ekslusi adalah superimposed preeklampsia, adanya riwayat hipertensi sebelum kehamilan atau ada tanda hipertensi kronis berdasarkan pemeriksaan optalmologi, mendapatkan obat-obatan yang mempengaruhi hasil pemeriksaan labor yang diteliti (prokoagulan, antikoagulan); dieksklusi berdasarkan data anamnesis, meninggal sebelum selesai stabilisasi, tidak diterminasi setelah stabilisasi selesai, mengundurkan diri dari sampel penelitian. Perbedaan perubahan temuan fungsi hemostatik pada kedua grup ini dianalisa menggunakan $t$ test.

\section{HASIL DAN PEMBAHASAN}

Pada penelitian ini didapat 32 sampel preeklampsia/eklampsia, yang terdiri dari 16 kasus yang mengalami perbaikan dan 16 kasus yang tidak mengalami perbaikan. Dari 32 sampel tersebut terdapat 4 kasus eklampsia, yaitu kasus nomor: 3, 8, 14 (kelompok yang mengalami perbaikan) dan nomor 22 (kelompok yang tidak mengalami perbaikan). Karakteristik sampel penelitian terlihat pada lampiran.

\section{Karakteristik Kedua Kelompok Penelitian}

1. Umur

Umur kelompok yang mengalami perbaikan adalah $(31,00+6,57267)$ tahun dan umur kelompok yang tidak mengalami perbaikan adalah $(34,6875+6,60019)$ tahun. Tidak terdapat perbedaan umur yang bermakna antara kedua kelompok $(p=0,124)$.

\section{Usia Kehamilan}

Usia kehamilan kelompok yang mengalami perbaikan adalah $(36,3750+3,30404)$ minggu dan usia kehamilan kelompok yang tidak mengalami perbaikan adalah $(33,8125+$ 4,32387) minggu. Tidak terdapat perbedaan usia kehamilan yang bermakna antara kedua kelompok $(p=0,069)$.

\section{Paritas}

Paritas kelompok yang mengalami perbaikan adalah $3,1250+2,12525$ dan paritas kelompok yang tidak mengalami perbaikan adalah $3,1250+1,82117$. Tidak terdapat perbedaan paritas yang bermakna antara kedua kelompok $(p=1,00)$. 


\section{Perubahan Temuan Laboratoris}

Perubahan temuan laboratoris terlihat pada lampiran. Beda Perubahan Temuan laboratoris Kedua Kelompok:

1. Trombosit

Kenaikan kadar trombosit pada kelompok yang mengalami perbaikan sebesar $(40,0000+$ $39,65350) \times 103 / \mathrm{ml}$ dan pada kelompok yang tidak mengalami perbaikan sebesar $(-5,2500+$ 58,91519) $\times 103 / \mathrm{ml}$ (terjadi penurunan). Kedua hasil ini berbeda bermakna dengan $p=0,016$.

\section{D-dimer}

Kenaikan kadar D-dimer pada kelompok yang mengalami perbaikan sebesar $(0,3188+$ 1,34026) ug/L dan pada kelompok yang tidak mengalami perbaikan sebesar $(0,7125+$ 2,01821) ug/L. Kedua hasil ini tidak berbeda bermakna dengan $p=0,521$.

\section{DISKUSI}

\section{Karakteristik}

Karakteristik kedua kelompok penelitian terlihat pada table 1. Dari tabel tersebut

Table 1. Karakteristik Kelompok Pasien Berdasarkan Umur, Usia Kehamilan dan Paritas

\begin{tabular}{|c|c|c|c|c|c|c|}
\hline No & Karakteristik & Kelompok & Rerata & SD & Beda Rerata & $\mathbf{P}$ \\
\hline \multirow{2}{*}{1} & \multirow{2}{*}{ Umur } & Perbaikan (+) & 31.0000 & 6.57267 & \multirow{2}{*}{3.6875} & \multirow{2}{*}{0.124} \\
\hline & & Perbaikan (-) & 34.6875 & 6.60019 & & \\
\hline \multirow{2}{*}{2} & \multirow{2}{*}{ Usia Kehamilan } & Perbaikan (+) & 36.3750 & 3.30404 & \multirow{2}{*}{2.5625} & \multirow{2}{*}{0,069} \\
\hline & & Perbaikan (-) & 33.8125 & 4.32387 & & \\
\hline \multirow{2}{*}{3} & \multirow{2}{*}{ Paritas } & Perbaikan (+) & 3.1250 & 2.12525 & \multirow{2}{*}{0.0} & \multirow{2}{*}{1.00} \\
\hline & & Perbaikan (-) & 3.1250 & 1.82117 & & \\
\hline
\end{tabular}

2. $\mathrm{PT}$

Kenaikan PT pada kelompok yang mengalami perbaikan sebesar $(-0,1438+1,08257)$ detik (terjadi pemendekan PT) dan pada kelompok yang tidak mengalami perbaikan sebesar $(0,0375+1,54871)$ detik (terjadi pemanjangan PT). Kedua hasil ini tidak berbeda bermakna dengan $p=0,074$.

\section{3. $\mathrm{APTT}$}

Kenaikan APTT pada kelompok yang mengalami perbaikan sebesar $(-, 2750+$ 3,93844) detik (terjadi pemendekan PT) dan
Terlihat bahwa tidak terdapat perbedaan karakteristik yang bermakna dalam hal umur, usia kehamilan dan paritas antara kedua kelompok. Dengan demikian kedua kelompok telah setara dari segi umur, usia kehamilan, dan paritas. pada kelompok yang tidak mengalami perbaikan sebesar $(1,5500+$ 4,99039) detik (terjadi pemanjangan PT). Kedua hasil ini tidak berbeda bermakna dengan $p=0,260$. 


\section{Perubahan Temuan Laboratoris}

Perubahan (gain score) temuan laboratoris kedua kelompok selama periode stabilisasi terlihat pada tabel 2 .

Tabel 2. Perubahan Temuan Laboratoris semakin berat atau berlanjutnya kerusakan endotel menyebabkan semakin banyak trombosit terpakai dan semakin berkurang jumlah/kadar trombosit. ${ }^{7}$

Pada penelitian ini terlihat bahwa kadar trombosit semakin menurun pada kelompok

\begin{tabular}{|c|c|c|c|c|c|c|}
\hline No & Unsur Laboratoris & Kelompok & Rerata & SD & Beda Rerata & $\mathbf{P}$ \\
\hline \multirow{2}{*}{1} & \multirow{2}{*}{ Trombosit } & Perbaikan $(+)$ & 40.0000 & 39.65350 & \multirow{2}{*}{45.2500} & \multirow{2}{*}{0.016} \\
\hline & & Perbaikan (-) & -5.2500 & 58.91519 & & \\
\hline \multirow{2}{*}{2} & \multirow{2}{*}{ PT } & Perbaikan (+) & -0.1438 & 1.08257 & \multirow{2}{*}{1.8130} & \multirow{2}{*}{0.704} \\
\hline & & Perbaikan (-) & 0.0375 & 1.54871 & & \\
\hline \multirow{2}{*}{3} & \multirow{2}{*}{ APTT } & Perbaikan (+) & -0.2750 & 3.93844 & \multirow{2}{*}{1.8250} & \multirow{2}{*}{0.260} \\
\hline & & Perbaikan (-) & 1.5500 & 4.99039 & & \\
\hline \multirow{2}{*}{4} & \multirow{2}{*}{ D-Dimer } & Perbaikan (+) & 0.3188 & 1.34026 & \multirow{2}{*}{0.3937} & \multirow{2}{*}{0.521} \\
\hline & & Perbaikan (-) & 0.7125 & 2.01821 & & \\
\hline
\end{tabular}

\section{Trombosit}

Dari kadar trombosit terlihat bahwa terjadi kenaikan kadar trombosit sebesar $40 \times 103 / \mathrm{ml}$ pada kelompok yang mengalami perbaikan. Kenaikan kadar trombosit ini lebih besar secara bermakna $(p=0,016)$ dibanding kenaikan kadar trombosit pada kelompok yang tidak mengalami perbaikan yang besarnya $-5,25 \times 103 / \mathrm{ml}$ (terjadi penurunan kadar trombosit). Dengan demikian Ho ditolak atau Ha diterima, yang berarti bahwa hipotesis penelitian-1 terbukti.

Menurut Kenny, Baker, and Cunningham (2009), pada preeklampsia/eklampsia terjadi penurunan jumlah dan pemendekan usia trombosit yang bermakna, dan ini ada hubungannya dengan faktor ekstrinsik (kerusakan endotel yang mengaktivasi trombosit). Kerusakan endotel memicu terjadinya agregasi trombosit, dan setiap agregasi trombosit menyebabkan makin berkurangnya trombosit. Oleh sebab itu yang tidak mengalami perbaikan. Hal itu disebabkan karena berlanjutnya atau semakin beratnya kerusakan endotel. Sedangkan pada kelompok yang mengalami perbaikan hal yang demikian tidak terjadi.

2. PT

Dari PT terlihat bahwa terjadi kenaikan PT sebesar -0,1438 detik (pemendekan PT) pada kelompok yang mengalami perbaikan. Kenaikan PT ini lebih kecil dibanding kenaikan PT pada kelompok yang tidak mengalami perbaikan yang besarnya 0,0375 detik, namun tidak bermakna secara statistik $(p=0,074)$. Dengan demikian Ho diterima atau Ha ditolak, yang berarti hipotesis-2 penelitian ini tidak terbukti. Namun demikian, secara kuantitas ada kecenderungan ke arah diterimanya hipotesis- 2 ini.

Menurut Kenny, Baker, and Cunningham (2009) pada preeklampsia/eklampsia terjadi gangguan kaskade koagulasi akibat gangguan fungsi protein-protein regulator, aktivitas 
antitrombin-III yang berkurang, kadar protein $S$ dan $C$ yang berkurang, dan trombofilia. Gangguan kaskade koagulasi juga bisa terjadi sebagai akibat lanjut banyaknya terpakai faktor pembekuan. Pada penelitian ini kecenderungan ke arah yang demikian terlihat dengan semakin memanjangnya PT pada kelompok yang tidak mengalami perbaikan, sedangkan pada kelompok yang mengalami perbaikan justru terjadi pemendekan. ${ }^{7}$

\section{3. $\mathrm{APTT}$}

Dari APTT terlihat bahwa terjadi kenaikan APTT sebesar -0,2750 detik (pemendekan APTT) pada kelompok yang mengalami perbaikan. Kenaikan APTT ini lebih kecil dibanding kenaikan APTT pada kelompok yang tidak mengalami perbaikan yang besarnya 1,5500 detik, namun tidak bermakna secara statistik $(p=0,260)$. Dengan demikian Ho diterima atau $\mathrm{Ha}$ ditolak, yang berarti hipotesis-3 penelitian ini tidak terbukti. Namun demikian, secara kuantitas ada kecenderungan ke arah diterimanya hipotesis3 ini.

Menurut Kenny, Baker, and Cunningham (2009) pada preeklampsia/eklampsia terjadi gangguan kaskade koagulasi akibat gangguan fungsi protein-protein regulator, aktivitas antitrombin-III yang berkurang, kadar protein $S$ dan $C$ yang berkurang, dan trombofilia. Gangguan kaskade koagulasi juga bisa terjadi sebagai akibat lanjut banyaknya terpakai faktor pembekuan. Pada penelitian ini kecenderungan ke arah yang demikian terlihat dengan semakin memanjangnya APTT pada kelompok yang tidak mengalami perbaikan, sedangkan pada kelompok yang mengalami perbaikan justru terjadi pemendekan APTT. ${ }^{7}$

\section{D-dimer}

Dari tabel 3 perihal kadar D-dimer terlihat bahwa terjadi kenaikan kadar sebesar 0,3188 ug/L pada kelompok yang mengalami perbaikan. Kenaikan kadar D-dimer ini lebih kecil dibanding kenaikan kadar D-dimer pada kelompok yang tidak mengalami perbaikan yang besarnya $0,7125 \mathrm{ug} / \mathrm{L}$, namun tidak bermakna secara statistik $(p=0,521)$. Dengan demikian Ho diterima atau Ha ditolak, yang berarti hipotesis-4 penelitian ini tidak terbukti. Namun demikian, secara kuantitas ada kecenderungan ke arah diterimanya hipotesis-4 ini.

Menurut Kenny, Baker, and Cunningham (2009) pada preeklampsia/eklampsia terjadi gangguan proses fibrinolisis akibat berkurangnya fibrinogen, berkurangnya tissue plasminogen activator, dan peningkatan PAI1. Derajad proses fibrinolisis antara lain dapat dilihat dari kadar D-dimer. Secara tidak langsung D-dimer menggambarkan aktifnya pembentukan trombus akibat proses koagulasi. Pada preeklampsia yang proses koagulasinya aktif akibat dipicu kerusakan endotel, maka akan didapatkan kadar D-dimer yang meningkat. Pada penelitian ini kecenderungan ke arah yang demikian terlihat dengan semakin meningkatnya kadar D-dimer pada kelompok yang tidak mengalami perbaikan dibandingkan peningkatan D-dimer pada kelompok yang mengalami perbaikan. ${ }^{7}$

\section{SIMPULAN}

Pada penelitian ini didapatkan peningkatan kadar trombosit pada kelompok preeklamsia berat/eklamsia yang mengalami perbaikan dibandingkan kelompok yang tidak mengalami perbaikan. Tidak terdapat perbedaan bermakna kadar PT, APTT, dan D- 
Dimer antara kelompok preeklamsia berat/eklamsia yang mengalami perbaikan dan

\section{DAFTAR RUJUKAN}

1. Lindheimer, M.D, Roberts, J.M, Cunningham, F.G, and Chesley, L. 'Introduction, History, Cotroversies, and Definitions'. In: Lindheimer, M.D, Roberts, J.M, and Cunningham, F.G. Chesley's Hypertensive Disorders in Pregnancy. 3rd ed. New York: Elsevier. 2009.

2. Dekker G. Hypertension. Dalam: High Risk Pregnancy 4th Edition. Elsevier Saunders, Philadelphia. 2011.

3. Silver HM, et al. Mechanism of increased maternal serum total activin $A$ and inhibin $A$ in preeclampsia. J Soc Gynecol Investig. 2008;9: 308-12.

4. Cunningham, F.G, McDonald, P.C, and Gant, N.F. William's Obstetrics. 18th ed. New York: Appleton \& Lange. 1989.

5. Roshadi R. Hipertensi Dalam Kehamilan. Dalam R. Hariadi, Ilmu Kedokteran Fetomaternal. Surabaya: Himpunan Kedokteran Fetomaternal Perhimpunan Obstetri dan Ginekologi Indonesia. 2004; hal. 494-500. kelompok yang tidak mengalami perbaikan.

6. Cunningham, F.G., Leveno, K.J., Bloom, S.I. et al. Williams Obstetrics. 23rd ed. New York: McRaw Hill. 2010.

7. Kenny, L, Baker, P.N, and Cunningham, F.G. 'Platelets, Coagulation, and Liver'. In: Lindheimer, M.D, Roberts, J.M, and Cunningham, F.G. Chesley's Hypertensive Disorders in Pregnancy. 3rd ed. New York: Elsevier. 2009.

8. Yang Liu et al. High Levels of Activin A Detected in Preeclamptic Placenta Induce Trophoblast Cell Apoptosis by Promoting Nodal Signaling.J Clin Endocrinol Metab 2012; 97(8):E1370E1379.

9. Troiano, N.H and Gaddipati, S. 'Invasive Hemodynamic and Oxygen Transport Monitoring During Pregnancy'. In: Troiano, N.H, Harvey, C.J and Chez, B.F. High-risk and Critical Care Obsterics. 2013. 3rd ed. New York: William \& Wilkins. 2013.

10.RS Dr. M. Djamil Padang. PPK SMF Kebidanan dan Kandungan. 2012. 